\title{
Pyrococcus yayanosii sp. nov., an obligate piezophilic hyperthermophilic archaeon isolated from a deep-sea hydrothermal vent
}

\author{
Correspondence \\ Daniel Prieur \\ daniel.prieur@univ-brest.fr
}

\author{
Jean-Louis Birrien, ${ }^{1,2,3}$ Xiang Zeng, ${ }^{1,4}$ Mohamed Jebbar, ${ }^{1,2,3}$ \\ Marie-Anne Cambon-Bonavita, ${ }^{5}$ Joël Quérellou, ${ }^{5}$ Philippe Oger, ${ }^{6,7,8}$ \\ Nadège Bienvenu, ${ }^{1,2,3}$ Xiang $\mathrm{Xiao}^{9}$ and Daniel Prieur ${ }^{1,2,3}$
${ }^{1}$ Université Bretagne Occidentale (UBO), IUEM (Institut Universitaire Européen de la Mer) - UMR 6197, Technopole Brest-Iroise, place Nicolas Copernic, F-29280 Plouzané, France
${ }^{2}$ CNRS, IUEM - UMR 6197, Technopole Brest-Iroise, place Nicolas Copernic, F-29280 Plouzané, France
${ }^{3}$ Université Européenne de Bretagne (UEB), 5 Boulevard René Laennec, F-35000 Rennes, France
${ }^{5}$ Ifremer, UMR 6197, Technopole Brest-Iroise, BP 70, F-29280 Plouzané, France
${ }^{7}$ CNRS, UMR 5570, Laboratoire de Sciences de la Terre, 15 parvis René Descartes BP 7000, Lyon, F-69342, France
${ }^{8}$ Laboratoire de Sciences de la Terre, Ecole Normale Supérieure de Lyon, 46 Allée d'Italie, 69364 Lyon Cedex, France \\ ${ }^{4} 3 r d$ Institute of Oceanography, SOA, Xiamen University, 361005 Xiamen, PR China \\ ${ }^{6}$ Université de Lyon, Lyon, France \\ ${ }^{9}$ School of Life Sciences \& Biotechnology, Shanghai Jiao Tong University, Shanghai, PR China
}

Since the discovery of deep-sea hydrothermal vents and socalled black smokers, many mesophilic, thermophilic and

\footnotetext{
Abbreviation: CRP, concatenated ribosomal protein.

The GenBank/EMBL/DDBJ accession number for the 16S rRNA gene sequence of strain $\mathrm{CH}^{\top}{ }^{\top}$ is EU682399.

Three supplementary figures and two supplementary tables are available with the online version of this paper.
}

hyperthermophilic micro-organisms of the superkingdoms Bacteria and Archaea have been described. Although vent fields have been explored at depths ranging from 800 to $3600 \mathrm{~m}$, rather few attempts have been made to enrich isolates under in situ pressures. Almost all thermophilic and hyperthermophilic vent-associated prokaryotes have been isolated under atmospheric pressure and few of them have been exposed to elevated hydrostatic pressures during culture. To our knowledge, only a few piezo-thermophilic 
organisms have been described so far: Thermococcus barophilus (Marteinsson et al., 1999a), Palaeococcus ferrophilus (Takai et al., 2000), Marinitoga piezophila (Alain et al., 2002), Methanopyrus kandleri (Takai et al., 2008) and two chemolithoautotrophic strains (Takai et al., 2009). T. barophilus and M. piezophila were isolated after enrichment cultures were grown at high temperatures and under elevated hydrostatic pressures, and showed highest growth rates when grown under hydrostatic pressures. Even if these organisms were able to grow under atmospheric pressure, their growth rates were much slower. Moreover, T. barophilus expressed a stress protein when grown under atmospheric pressure (Marteinsson et al., 1999b) and M. piezophila formed long filaments.

In March 2007, black smoker samples were collected during the Serpentine cruise at a depth of $4100 \mathrm{~m}$ at the Ashadze site $\left(12^{\circ} 58.4^{\prime} \mathrm{N} 44^{\circ} 51.8^{\prime} \mathrm{W}\right)$ located on the Mid-Atlantic Ridge (MAR) (Fouquet et al., 2007). Samples were collected using the ROV Victor 6000, which was operated from the Pourquoi Pas? research vessel. The samples were immediately placed in a sterile sampling box, previously filled on-board with sterile freshwater, which was opened as close as possible to the sampling site and then tightly closed with a lid. Once on board, chimney samples were immediately crushed under sterile conditions in an anaerobic chamber and then immediately distributed into syringes containing artificial seawater, which was reduced with $\mathrm{Na}_{2} \mathrm{~S}$. The samples were then pressurized at $40 \mathrm{MPa}$ and placed at $4{ }^{\circ} \mathrm{C}$ for storage prior to analysis. The whole procedure was carried out anaerobically. In the laboratory, samples were depressurized on ice at room temperature and 0.5 to $1 \mathrm{ml}$ of the rock suspensions were rapidly transferred for initial enrichment into $10 \mathrm{ml}$ syringes loaded with modified MJYP medium (Takai et al., 2000), which was adjusted to pH 7 and supplemented with $20 \mathrm{mM} \mathrm{NaNO}_{3}, 5 \mathrm{mM} \mathrm{FeSO}_{4}$ and $1 \mathrm{mg}$ rezasurin $\mathrm{l}^{-1}$ for monitoring anaerobiosis. The syringes were then placed into the high-pressure/high-temperature incubation system, which was custom-built by Top Industrie (Dammarie-les-Lys, France), pressurized to $42 \mathrm{MPa}$ (corresponding to the in situ pressure) and heated at 85, 95 or $105{ }^{\circ} \mathrm{C}$ (Marteinsson et al., 1997). All experiments were conducted in duplicate.

After 2 days of incubation under strictly anaerobic conditions, a growing culture was observed and an isolate, designated strain $\mathrm{CH}_{1}{ }^{\mathrm{T}}$, was successfully purified using the dilution-to-extinction technique under $42 \mathrm{MPa}$ pressure at $95{ }^{\circ} \mathrm{C}$. The purity of the isolate was confirmed by microscopic observation and by cloning and sequencing the $16 \mathrm{~S}$ rRNA gene. Cells of strain $\mathrm{CH}^{\mathrm{T}}$ were obtained during exponential growth phase and stored anaerobically in $1.8 \mathrm{ml}$ cryotubes for long-term storage, at $-80{ }^{\circ} \mathrm{C}$, after addition of dimethyl sulfoxide $(5 \%, \mathrm{v} / \mathrm{v})$ (Sigma) as cryoprotectant.

Cells of strain $\mathrm{CH}^{\mathrm{T}}$ were observed using a light microscope equipped with a phase-contrast oil-immersion objective (model BH2; Olympus) and appeared as slightly irregular cocci, $1-1.5 \mu \mathrm{m}$ in diameter, that divided by constriction and occurred singly or in pairs but sometimes in line. The cells were highly motile and specific coloration, using the Spot Test Flagella kit (Difco), revealed a polar tuft of flagella (Supplementary Fig. S1, available in IJSEM Online). The Gram staining reaction was negative.

Since better growth occurred in Thermococcales Rich Medium (TRM; Zeng et al., 2009), all further investigations for determination of growth parameters under high hydrostatic pressures were conducted in $5 \mathrm{ml}$ syringes containing TRM inoculated with $1 \%$ late-exponential phase culture $\left(\sim 1.10^{8}\right.$ cells $\left.\mathrm{ml}^{-1}\right)$ grown under $42 \mathrm{MPa}$ pressure at $95{ }^{\circ} \mathrm{C}$. Cells grown under specific conditions were collected at regular intervals and growth was estimated by direct cell counting using a Thomas chamber (depth $0.02 \mathrm{~mm}$ ). All samples were tested in duplicate.

Strain $\mathrm{CH}^{\mathrm{T}}$ grew only under strictly anaerobic conditions and within a temperature range of 80 to $108{ }^{\circ} \mathrm{C}$ with optimum growth at $98{ }^{\circ} \mathrm{C}$. It grew under high-pressure conditions within the range of 20 to $120 \mathrm{MPa}$ with an optimum of $52 \mathrm{MPa}$ when tested at optimal growth temperature of $98{ }^{\circ} \mathrm{C}$. No growth was observed at pressures below $20 \mathrm{MPa}$ or above $120 \mathrm{MPa}$ (Supplementary Fig. S2). Strain $\mathrm{CH}_{1}^{\mathrm{T}}$ required salt and grew at concentrations ranging from 2.5 to $5.5 \%(\mathrm{w} / \mathrm{v}) \mathrm{NaCl}$, with an optimum of $\sim 3.5 \%$. No growth was observed below $2.5 \%$ or above $5.5 \%(\mathrm{w} / \mathrm{v})$ $\mathrm{NaCl}$. The isolate grew at $\mathrm{pH} 6.0-9.5$, with an optimum of $\sim \mathrm{pH} 7.5-8$. No growth was detected at pH 5.5 or 10 .

Growth requirement and substrate utilization tests were performed in syringes using exponential-phase cells at a final concentration of $5 \times 10^{5}$ cells $\mathrm{ml}^{-1}$. Incubations were carried out at optimal pressure $(52 \mathrm{MPa})$ and temperature $\left(98{ }^{\circ} \mathrm{C}\right)$ for growth. Various single carbon sources were added to a basal TRM ( $\mathrm{pH} 7.5$ ), supplemented with a small amount of yeast extract $(0.002 \%, \mathrm{w} / \mathrm{v})$ for culture initiation. The following carbon sources, all at a final concentration of $0.2 \%(\mathrm{w} / \mathrm{v})$, were tested: yeast extract, Peptone, Tryptone, casein, glycogen, starch, chitin, acetate, formate, propionate, pyruvate, succinate, cellobiose, galactose, glucose, maltose, sucrose, ethanol, glycerol, Casamino acids and tryptophan.

Nitrogen sources were tested on TRM mineral medium prepared without $\mathrm{NH}_{4} \mathrm{Cl}$ and Tryptone but with sucrose $(0.2 \%, \mathrm{w} / \mathrm{v})$ as the carbon and energy source and $5 \mathrm{~g}$ sulfur $1^{-1}$ as the electron acceptor. Hydrolysis of urea, glutamate and gelatin was determined by testing each substrate at a concentration of $0.2 \%(\mathrm{w} / \mathrm{v})$, while utilization of $\mathrm{NH}_{4} \mathrm{Cl}$, $\mathrm{KNO}_{3}$ and $\mathrm{KNO}_{2}$ was determined by using $20 \mathrm{mM}$ of each substrate added to the basal medium. To examine the ability of the isolate to grow in the absence of elemental sulfur, cells were cultured in TRM medium without sulfur; L-cystine $\left(5 \mathrm{~g}^{-1}\right)$ and thiosulfate $(20 \mathrm{mM})$ were also tested. Nitrate, sulfate and thiosulfate were tested as potential electron acceptors with succinate as a carbon source.

Growth was recorded after 2 and 4 days of incubation. Negative (uninoculated TRM) and positive (inoculated 
TRM containing yeast extract and Peptone) controls were performed for each substrate. All tests were performed in duplicate. For all tests, positive cultures were transferred ( $10 \%$ inoculum) into the test media for confirmation of growth. The results of these experiments are presented in Table 1. No growth was observed on the control medium containing yeast extract $(0.002 \%)$ only.

Strain $\mathrm{CH}^{\mathrm{T}}$ used a variety of proteinaceous substrates and carbohydrates as carbon and energy sources since sulfate, nitrate and thiosulfate were not used as electron acceptors. Growth was greatly enhanced by the addition of sulfur and cystine but was only slightly enhanced by thiosulfate. In all cases, hydrogen sulfide was produced.

For genomic analyses, DNA was prepared from cells harvested at the end of the exponential phase using chemical extraction (Barbier et al., 1999).

The $\mathrm{G}+\mathrm{C}$ content of the DNA was determined by thermal denaturation (Marmur \& Doty, 1962) using the conditions reported by Raguénès et al. (1997). A calibration curve was obtained by using ultrapure DNA (Sigma) from Escherichia coli Strain B (50 mol\%), Clostridium perfringens (26.5 mol\%)

Table 1. Characteristics of strain $\mathrm{CH}^{\top}$ and related members of the genus Pyrococcus

Taxa: 1, strain $\mathrm{CH}^{\mathrm{T}}$; 2, P. furiosus $\mathrm{Vcl}^{\mathrm{T}}$ (=DSM $3638^{\mathrm{T}}$ ); 3, 'P. abyssi GE5 (=CNCM I 1302); 4, P. horikoshii JCM 9974 ${ }^{\mathrm{T}}$; 5 , P. glycovorans AL585 ${ }^{\mathrm{T}}$ $\left(=\mathrm{CNCM} \mathrm{I}-2120^{\mathrm{T}}\right)$. All strains grew with complex substrates as sole carbon and energy sources including yeast extract, peptone and tryptone. + , Positive; -, negative; (+), weakly positive. ND, not determined.

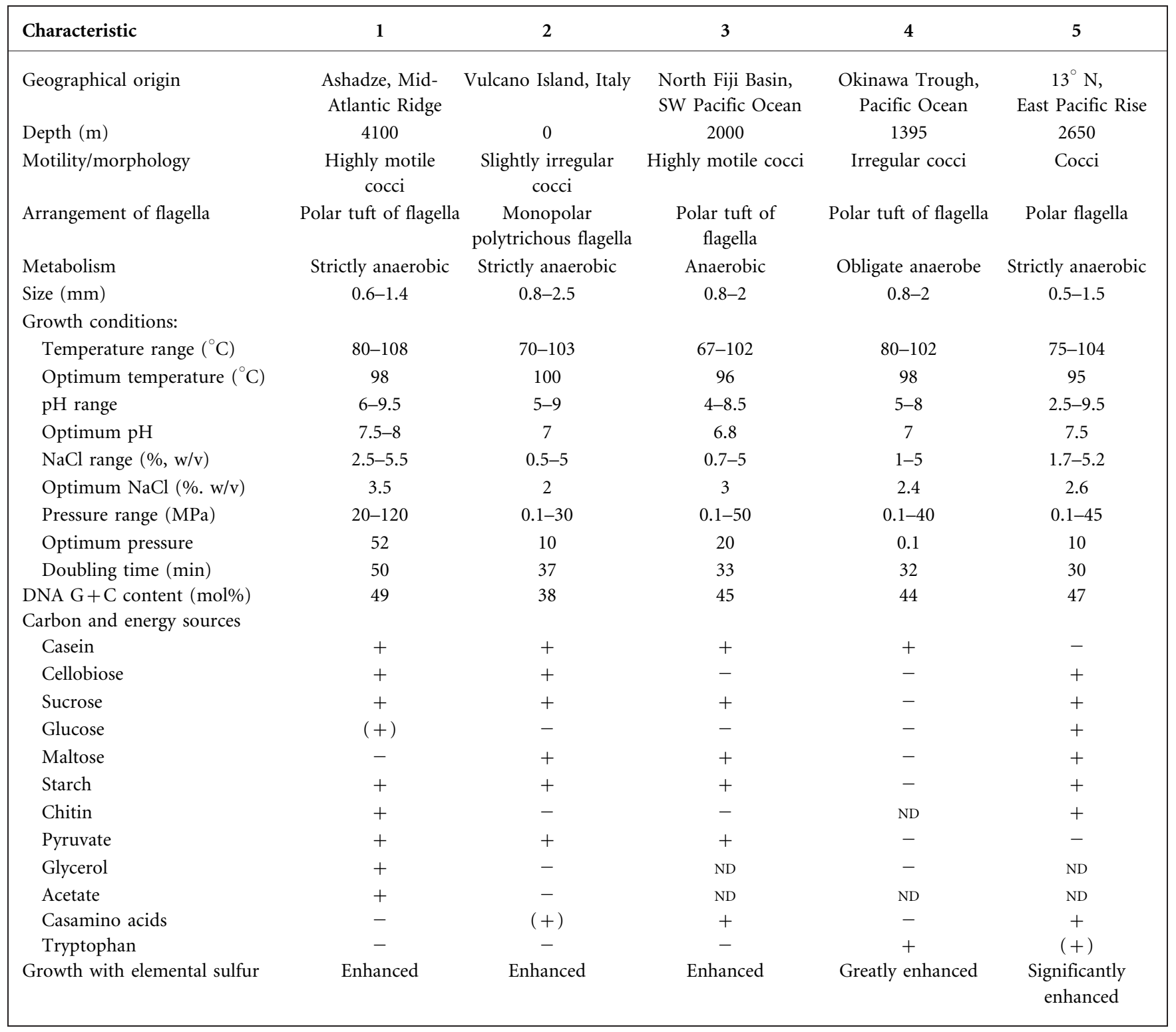


and Micrococcus luteus (72 mol\%) as standards. The $\mathrm{G}+\mathrm{C}$ content of the genomic DNA of strain $\mathrm{CH}^{\mathrm{T}}$ was $49.0 \pm 0.5 \mathrm{~mol} \%$.

16S rRNA genes were amplified using the archaeal 16S rRNA gene universal primers A8f (5'-CGGTGGATCCTGCCGGA-3') and U1492r (5'-GTTACCTTGTTACGACTT-3'). Analysis of the $16 \mathrm{~S}$ rRNA gene sequence of strain $\mathrm{CH}^{\mathrm{T}}$ (1424 bp) indicated that it belonged to the genus Pyrococcus and was most closely related to Pyrococcus furiosus, sharing $99.4 \%$ sequence similarity (Supplementary Fig. S3). High 16S rRNA gene sequence similarity levels between two species of the genus Pyrococcus is common and was also observed between ' $P$. abyssi' and $P$. horikoshii (Supplementary Table S1). With such high 16S rRNA gene sequence similarities, DNA-DNA hybridization should normally be performed (Stackebrandt \& Goebel, 1994; Rosselló-Mora \& Amann, 2001); however, in the present study, DNA could not be obtained in the amounts needed to perform DNA-DNA hybridization as strain $\mathrm{CH}^{\mathrm{T}}$ could only grow under pressure and, as such, cultures only reached low cell densities. Consequently, an alternative method was performed. It has been demonstrated that ribosomal proteins are good phylogenetic markers (Matte-Tailliez et al., 2002; Brochier-Armanet et al., 2008) and, in analyses, give high resolution at the species level. A complete genome sequencing project of strain $\mathrm{CH}^{\mathrm{T}}$ has been completed (Jun et al., 2011). Ribosomal protein sequences were retrieved from available contigs of the raw genome sequence using the tblastn option in the BLAST program (Altschul et al., 1990). Ribosomal protein sequences ( 59 in total) common to strain $\mathrm{CH}^{\mathrm{T}}$, ' $P$. abyssi', P. horikoshii, P. furiosus and Thermococcus kodakaraensis were concatenated to produce a single protein sequence of $\sim 8100$ residues. Concatenated ribosomal protein (CRP) sequences (Supplementary Table S2) were aligned using CLUSTAL_X (Thompson et al., 1994). CRP sequence similarities were obtained by pairwise alignment using different protein matrices: identity, Blosum 50, PAM 250 and Gonnet. CRP sequence similarities were compared with similarity levels between $16 \mathrm{~S}$ rRNA gene sequences and with published results of DNA-DNA reassociation levels between already characterized members of the genus Pyrococcus. A phylogenetic tree based on CRP sequences was reconstructed using the program PHYLO-WIN (Galtier et al., 1996) with T. kodakaraensis as an outgroup.

The type of substitution matrix used did not change the results significantly (Supplementary Table S2). When each couple of reference species was compared for both DNADNA reassociation and CRP sequence similarity levels, it appeared that the highest CRP similarity level (96.2\%) was observed between ' $P$. abyssi' and $P$. horikoshii. All other CRP sequence similarity levels between strain $\mathrm{CH}^{\mathrm{T}}$ and other reference species were lower (92.2-92.8\%) indicating that strain $\mathrm{CH}^{\mathrm{T}}$ was a distinct species. In addition, the phylogenetic tree based on CRP sequences clearly separated strain $\mathrm{CH}^{\mathrm{T}}$ from reference strains of the genus Pyrococcus, having a very strong tree topology with $100 \%$ bootstrap support for the node separating $\mathrm{CH}^{\mathrm{T}}$ from other members of the genus Pyrococcus (Fig. 1).

In conclusion, $P$. yayanosii appears to be the most thermophilic species among members of the order Thermococcales but is less thermophilic than the record holder, the piezophilic methanogen Methanopyrus kandleri (Takai et al., 2008).

Following discussions held at the meetings of the International Committee on Systematics of Prokaryotes (ICSP) and its Judicial Commission (JC) in San Francisco in 2005, a committee, consisting of the Chairman of the ICSP, the Chairman of the JC of the ICSP and the Editor in Chief of the International Journal of Systematic and Evolutionary Microbiology, have granted an exception, in this instance, to Rule 27(3) of the Bacteriological Code governing the deposit of a type strain in two recognized collections in two different countries. Pyrococcus yayanosii $\mathrm{CH}^{\mathrm{T}}$ is available on request from the 'Souchothèque de Bretagne' culture collection. Attempts are still under way to complete the deposition of the type strain in a second recognized culture collection.

\section{Description of Pyrococcus yayanosii sp. nov.}

Pyrococcus yayanosii (ya.ya.nos'i.i. N.L. gen. n. yayanosii of Yayanos, in honour of Aristides Yayanos, a pioneer in the study of piezophilic bacteria).

Cells are motile cocci (1-1.5 $\mu \mathrm{m}$ in diameter) with a polar tuft of flagella. Growth occurs at $80-108{ }^{\circ} \mathrm{C}$ (optimum $95{ }^{\circ} \mathrm{C}$ ) and under $20-120 \mathrm{MPa}$ hydrostatic pressure (optimum $52 \mathrm{MPa}$ ). No growth occurs at any temperature at pressures below $20 \mathrm{MPa}$. Growth occurs at $\mathrm{pH}$ 6.0-9.5 (optimum $\mathrm{pH} 7.5-8.0$ ) and in 2.5-5.5\% (w/v) $\mathrm{NaCl}$ (optimum 3.5\%). Growth occurs under strictly anaerobic conditions by fermentation of simple or complex substrates. Nitrate, sulfate and thiosulfate are not used as electron acceptors. Yeast extract, Peptone, Tryptone, cellobiose, sucrose, starch, chitin, pyruvate, acetate and glycerol are used as substrates for fermentation. Maltose, Casamino acids and tryptophan are not utilized. Hydrogen sulfide is produced when elemental sulfur, thiosulfate or cystine is added to the media. Growth is enhanced by elemental sulfur. Urea, glutamate, gelatin, $\mathrm{NH}_{4} \mathrm{Cl}, \mathrm{KNO}_{3}$ and $\mathrm{KNO}_{2}$ were not used as nitrogen sources.

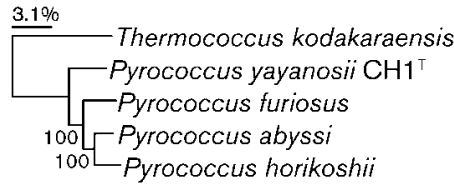

Fig. 1. Neighbour-joining phylogenetic tree based on concatenated ribosomal protein sequences (8016 sites) of members of the genus Pyrococcus. Thermococcus kodakaraensis was used as an outgroup. Bootstrap values, based on 500 replicates, are given at branch points. Bar, $3.1 \%$ sequence divergence. 
The type strain, $\mathrm{CH}^{\mathrm{T}}\left(=\mathrm{JCM} 16557^{\mathrm{T}}\right)$, was isolated from an active deep-sea hydrothermal chimney at a depth of $4100 \mathrm{~m}$ at the Ashadze site on the Mid-Atlantic Ridge $\left(12^{\circ}\right.$ $58.4^{\prime} \mathrm{N} 44^{\circ} 51.8^{\prime} \mathrm{W}$ ). The type strain is also available on request from the 'Souchothèque de Bretagne' (catalogue LMBE) culture collection (http://www.ifremer.fr/souchotheque/). The DNA G + C content of the type strain is $49 \pm 0.5 \mathrm{~mol} \%$.

\section{Acknowledgements}

We thank Y. Fouquet and G. Cherkasho, Chief scientists of the Serpentine cruise, the captain and the crew of the RV Pourquoi Pas?, the ROV Victor 6000 team, and F. Lesongeur for DNA G + C content analysis. This work was supported by UBO/IUEM, CNRS, Ifremer, the ANR project DEEP-OASES and a partenariat Hubert Curien (PHC) PFCC collaboration grant from Egide, awarded to M. J.

\section{References}

Alain, K., Marteinsson, V. T., Miroshnichenko, M. L., BonchOsmolovskaya, E. A., Prieur, D. \& Birrien, J. L. (2002). Marinitoga piezophila sp. nov., a rod-shaped, thermo-piezophilic bacterium isolated under high hydrostatic pressure from a deep-sea hydrothermal vent. Int J Syst Evol Microbiol 52, 1331-1339.

Altschul, S. F., Gish, W., Miller, W., Myers, E. W. \& Lipman, D. J. (1990). Basic local alignment search tool. J Mol Biol 215, 403-410.

Barbier, G., Godfroy, A., Meunier, J. R., Quérellou, J., Cambon, M. A., Lesongeur, F., Grimont, P. A. D. \& Raguénès, G. (1999). Pyrococcus glycovorans sp. nov., a hyperthermophilic archaeon isolated from the East Pacific Rise. Int J Syst Bacteriol 49, 1829-1837.

Brochier-Armanet, C., Boussau, B., Gribaldo, S. \& Forterre, P. (2008). Mesophilic Crenarchaeota: proposal for a third archaeal phylum, the Thaumarchaeota. Nat Rev Microbiol 6, 245-252.

Fouquet, Y., Cherkashov, G., Charlou, J.-L., Ondreas, H., Cannat, M., Bortnikov, N., Silantiev, S., Etoubleau, J. \& Scientific Party (2007). Diversity of ultramafic hosted hydrothermal deposits on the Mid-Atlantic Ridge: First submersible studies of Ashadze, Logatchev 2, and Krasnov vent fields during the Serpentine Cruise. Eos Trans AGU, 88 (52), Fall Meeting Suppl., Abstract T51F-03.

Galtier, N., Gouy, M. \& Gautier, C. (1996). SEAVIEW and PHYLO_WIN: two graphic tools for sequence alignment and molecular phylogeny. Comput Appl Biosci 12, 543-548.

Jun, X., Lupeng, L., Minjuan, X., Oger, P., Fengping, W., Jebbar, M. \& Xiang, $X$. (2011). Complete genome sequence of the obligate piezophillic archaeon Pyrococcus yayanosii CH1. J Bacteriol 193, 4297-4298.

Marmur, J. \& Doty, P. (1962). Determination of the base composition of deoxyribonucleic acid from its thermal denaturation temperature. J Mol Biol 5, 109-118.
Marteinsson, V. T., Moulin, P., Birrien, J. L., Gambacorta, A., Vernet, M. \& Prieur, D. (1997). Physiological responses to stress conditions and barophilic behaviour of the hyperthermophilic archaeon Pyrococcus abyssi. Appl Environ Microbiol 93, 1230-1236.

Marteinsson, V. T., Birrien, J. L., Reysenbach, A. L., Vernet, M., Marie, D., Gambacorta, A., Messner, P., Sleytr, U. B. \& Prieur, D. (1999a). Thermococcus barophilus sp. nov., a new barophilic and hyperthermophilic archaeon isolated under high hydrostatic pressure from a deepsea hydrothermal vent. Int J Syst Bacteriol 49, 351-359.

Marteinsson, V. T., Reysenbach, A. L., Birrien, J. L. \& Prieur, D. (1999b). A stress protein is induced in the deep-sea barophilic hyperthermophile Thermococcus barophilus when grown under atmospheric pressure. Extremophiles 3, 277-282.

Matte-Tailliez, O., Brochier, C., Forterre, P. \& Philippe, H. (2002). Archaeal phylogeny based on ribosomal proteins. Mol Biol Evol 19, 631-639.

Raguénès, G., Christen, R., Guézennec, J., Pignet, P. \& Barbier, G. (1997). Vibrio diabolicus sp. nov., a new polysaccharide-secreting organism isolated from a deep-sea hydrothermal vent polychaete annelid, Alvinella pompejana. Int J Syst Bacteriol 47, 989-995.

Rosselló-Mora, R. \& Amann, R. (2001). The species concept for prokaryotes. FEMS Microbiol Rev 25, 39-67.

Stackebrandt, E. \& Goebel, B. M. (1994). Taxonomic note: a place for DNA-DNA reassociation and $16 \mathrm{~S}$ rRNA sequence analysis in the present species definition in bacteriology. Int J Syst Bacteriol 44, 846849.

Takai, K., Sugai, A., Itoh, T. \& Horikoshi, K. (2000). Palaeococcus ferrophilus gen. nov., sp. nov., a barophilic, hyperthermophilic archaeon from a deep-sea hydrothermal vent chimney. Int J Syst Evol Microbiol 50, 489-500.

Takai, K., Nakamura, K., Toki, T., Tsunogai, U., Miyazaki, M., Miyazaki, J., Hirayama, H., Nakagawa, S., Nunoura, T. \& Horikoshi, K. (2008). Cell proliferation at $122{ }^{\circ} \mathrm{C}$ and isotopically heavy $\mathrm{CH}_{4}$ production by a hyperthermophilic methanogen under high-pressure cultivation. Proc Natl Acad Sci U S A 105, 10949-10954.

Takai, K., Miyazaki, M., Hirayama, H., Nakagawa, S., Quérellou, J. \& Godfroy, A. (2009). Isolation and physiological characterization of two novel, piezophilic, thermophilic chemolithoautotrophs from a deep-sea hydrothermal vent chimney. Environ Microbiol 11, 19831997.

Thompson, J. D., Higgins, D. G. \& Gibson, T. J. (1994). Clustal W: improving the sensitivity of progressive multiple sequence alignment through sequence weighting, position-specific gap penalties and weight matrix choice. Nucleic Acids Res 22, 4673-4680.

Zeng, X., Birrien, J. L., Fouquet, Y., Cherkashov, G., Jebbar, M., Quérellou, J., Oger, P., Cambon-Bonavita, M. A., Xiao, X. \& Prieur, D. (2009). Pyrococcus $\mathrm{CH} 1$, an obligate piezophilic hyperthermophile: extending the upper pressure-temperature limits for life. ISME $J \mathbf{3}$, 873-876. 